\title{
A Field Study on Group Housing of Lactating Sows with Special Reference to Sow Health at Weaning
}

\author{
By F. Hultén ${ }^{1}$, N. Lundeheim ${ }^{2}$, A.-M. Dalin 1 and S. Einarsson ${ }^{1}$ \\ ${ }^{1}$ Department of Obstetrics and Gynaecology, and ${ }^{2}$ Department of Anımal Breeding and Genetics, Swedish \\ University of Agricultural Sciences, Uppsala, Sweden.
}

\begin{abstract}
Hultén, F., N. Lundeheim, A.-M. Dalin and S. Einarsson: A field study on group housing of lactating sows with special reference to sow health at weaning. Acta vet. scand. 1995, 36, 201-212. - Four farms that group-housed sows from 2 weeks of lactation until weaning (G-farms) and 3 farms that kept the sows individually penned throughout the 5 to 6-week-long lactation period (C-farms), were compared in terms of sow health. All sows were crossbred Swedish Yorkshire $\times$ Swedish Landrace. The daily food ration was similar on all farms except during the group-housing period, when G-farm sows were fed ad libitum. Sows were grouped in the breeding section and kept grouped on deep litter in the dry sow section on all farms. Individual health examinations were performed at the time of weaning ( \pm 4 days) on $179 \mathrm{G}$-farm sows and on $167 \mathrm{C}$-farm sows. Teat- and udder skin wounds occurred less frequently $(\mathrm{p}<0.001)$ in G-farm sows than in C-farm sows. In addition, preweaning atrophy of all mammary glands occurred in $6.6 \%$ of the G-farm-sows but not in a single C-farm sow $(\mathrm{p}<0.001)$. This indicates that sow-piglet interactions decrease when sows are group housed. However, these differences did not occur in primıparous sows, suggesting that the relation between the primiparous sow and her litter is not affected. Mastitis frequency was the same in the 2 systems. Moreover, the frequency of locomotor disorders was the same in the 2 groups, and hoof overgrowth was common in both systems. These similarities could be due to the fact that all farms group housed dry sows on deep litter. A strong relation $(\mathrm{p}<0.001)$ between hoof overgrowth and locomotor disorders was evident. Low access to food due to low rank among primiparous group-housed sows was indicated by a lower $(p<0.05)$ backfat thickness compared with multiparous sows, and a higher $(p<0.001)$ frequency of skın wounds compared with indıvidually housed primiparous sows.
\end{abstract}

lactation; culling; loose-housing; udder; locomotion; backfat.

\section{Introduction}

The social structure of a wild boar population is well organized, consisting of groups of females with their offspring, along with solitary ranging males that only associate with the groups at times when females are sexually receptive (Signoret et al. 1975, Mauget 1981). The ability to establish a social structure and express the natural behaviour associated with farrowing and lactation has not been lost through domestication. Thus a domesticated sow kept in a natural environment separates from the group 1-2 days before farrowing (Lent 1974, Jensen 1986) and builds a farrowing nest (Jensen 1986, Jensen et al. 1987). She stays in the nest for about 10 days after parturition, during which time the social bonds between the sow and her litter are established 
(Jensen \& Redbo 1987), and she then reunites with the group (Jensen 1986, Stangel \& Jensen 1991). Based on this knowledge a commercial-scale group-housing system for lactating sows has been developed. The sows are kept in individual pens from a few days before farrowing until the second week of lactation, after which they are housed in groups until weaning. The group-housing system is considered to increase welfare because it allows the sows to express their natural behaviour. Stereotypic behaviour is seen less frequently among group-housed swine than among individually housed animals (Lambert et al. 1983). However, agonistic behaviour occurs in the process of establishing and maintaining a dominance hierarchy (Meese \& Ewbank 1973, Jensen \& Wood-Gush 1984). The level of aggression is highest during the first days after mixing unfamiliar animals, but decreases abruptly once the social structure has been established. (Meese \& Ewbank 1973). Moreover, the suckling behaviour changes when sows are grouped during lactation (Bryant et al. 1983, Bryant \& Rowlinson 1984) and cross suckling occurs during the lactation period (Newberry \& Wood-Gush 1985, Andreasson \& Andersson 1992). In order to assess sow welfare and performance in the group-housing system for lactating sows the effects of housing conditions on sow health and behaviour have to be considered, in addition to the knowledge of behavioural effects of this system. In conventional housing systems, where sows are housed singly during lactation, abscesses in the mammary gland ( Delgado \& Jones 1981, Bollwahn \& Meermeier 1989), leg weakness and lameness (Bäckström 1973, Dewey et al. 1988) and excessive loss of backfat (Whittemore et al. 1980) are frequently observed at the end of lactation.

The objective of the present study was to evaluate sow health in commercially used group- housing systems for lactating sows by performing health examinations at weaning.

\section{Materials and methods}

The study was performed at 7 commercial farms during 1 year. In 4 farms the sows farrowed in individual pens and were group housed from about 2 weeks after farrowing until weaning (G-farms), whereas in the other 3 farms, used as controls, the sows were kept in individual pens throughout the lactation period (C-farms). There were 540 sows in the G-farm group and 300 in the $\mathrm{C}$-farm group. Herd size varied between 75 and 220 sows in the G-farm group, and between 65 and 140 sows in the $\mathrm{C}$-farm group. The Gfarms resembled each other regarding management techniques, and the $\mathrm{C}$-farms resembled the G-farms in all aspects except for the lactation period. In choosing study farms a precondition was that the housing systems had been in place for at least 1 year before initiating the investigation. In addition, the farms selected were geographically separated in the south-central region of Sweden; thus local differences in management routines were included. All sows were crossbred Swedish Yorkshire $\times$ Swedish Landrace, and according to information from the veterinarians responsible for health of the herds, none of them were affected by any epidemic diseases at the beginning of the study.

\section{General management routine}

The sows farrowed in batches that consisted of 8 to 22 animals. The average size of the farrowing pens was $7.2 \mathrm{~m}^{2}$ in both groups. They had a concrete floor, and were once or twice daily provided with a small amount of straw. Fostering was practised within the same batch to even litter size, and the piglets' teeth were either cut or ground on all farms but 1 of the 
G-farms, where teeth were cut only in firstparity litters or litters with more than 10 piglets. On the C-farms sows were kept in pens throughout lactation, whereas on the G-farms they were group housed when the last litter born in the same batch of sows was at least 10 days old. All sows from the same batch were moved to the same group-housing section, and immediately thereafter the piglets were brought to them. The group-housing sections allowed $6-8 \mathrm{~m}^{2}$ per sow and consisted of isolated buildings with deep litter on a concrete floor. Water was supplied ad libitum through valves. In the group-housing section (Gfarms) sow food was provided either in dryfood self feeders that served 3 sows each, or in troughs at which each sow had $40 \mathrm{~cm}$ of eating space. The lactation period was 5-6 weeks, during which time the sows had no boar contact. Sows were group housed in the breeding section, and on all farms, dry sows were grouped indoors on deep litter. Furthermore, in all herds the same vaccination/prophylactic treatment routines were used against erysipelas, parvovirus infection, and endo- and ectoparasites.

In 2 of the G-farms and in 1 of the C-farms liquid feeding was practised (grain, commercial premix and whey), whereas in the other farms the food was given dry. The average daily food ration for dry sows was similar for the 2 groups (25-26 MJ/sow, $120-170 \mathrm{~g}$ crude protein/kg dry matter). The food ration was gradually increased beginning 1 to 2 days after farrowing, and the maximum ration was reached between days 10 and 14 of lactation. The average daily food ration was then 88-90 MJ (150$160 \mathrm{~g}$ crude protein/kg dry matter) per sow with 10 piglets. In the $\mathrm{C}$-farm group this ration level was maintained throughout lactation, whereas in the G-farm group sows were fed ad libitum during the group housing period. The piglets were creep fed, in areas off limits to the sows, from the first week of lactation until weaning.

\section{Design}

Clinical health examinations, including body temperature, backfat thickness, udder health, legs and gait, external genital tract and skin, were performed by the same veterinarian on 179 sows in the G-farms and on 167 sows in the C-farms, on the day of weaning ( \pm 4 days). A body temperature exceeding 39.5 was considered as fever. Wounds on teats and on mammary skin were noted, and the number of mammary glands affected was recorded (4 classes:1-3, 4-6, 7-9 and 10). Preweaning mammary gland atrophy was recorded in sows examined within 2 days after weaning, but was considered only if all mammary glands were affected. Mastitis was recorded if - through palpation - a focal or diffuse increase in mammary gland density was found, occasionally with a discoloration and/or oedema. In addition, mastitis in a feverish sow was denoted acute mastitis, while mastitis in sows with normal body temperature was designated chronic mastitis. Furthermore, lameness or abnormal walk (stiffness or an abnormal swaying gait) was recorded by allowing the sow to walk freely about 5-10 meters in a passage, with concrete flooring, adjacent to the pen. All hooves on every sow were examined for cleft and abscess formation, and for hoof overgrowth. A hoof was considered to be overgrown if the angle between the dorsal surface of the wall and the sole visually appeared abnormally acute. The ventral surface of the hoof was not examined and the different insults were not scored. Joint remarks include swellings, deformities, bursitis and exostosis in the tarsal, carpal, and proximal phalangeal joints. The occurrence of discharge and wounds in the external genital tract were noted, and wounds or abscesses were also re- 
Table 1. Litter size at birth and at time of grouping. Interval between farrowing and grouping, grouping and weaning, and farrowing and weaning (least square means).

\begin{tabular}{lccc}
\hline & G-farm group & C-farm group & Level of significance \\
\hline No of sows & 179 & 167 & \\
Litter size: & & & \\
- at birth & 11.8 & 11.7 & N.S. \\
- at day of groupig1) & 9.9 & 9.8 & N.S. \\
Interval (days): & 19.2 & & \\
Farrowing-Grouping1) & 19.6 & 16.0 & N.S. \\
Grouping - Weaning1) & 38.8 & 18.8 & N.S. \\
Farrowing - Weaning & 34.5 & N.S. \\
\hline
\end{tabular}

1) In the $C$-farms litter size was determıned at a tıme corresponding to the time of grouping in the G-farms.

corded at skin examination. Ultrasonic measurement of backfat thickness was made at the last rib approximately $8 \mathrm{~cm}$ from the middle of the back. Litter data was recorded by the farmers. On the $\mathrm{C}$-farms, litter size was determined at the time corresponding to the time of grouping on the G-farms.

\section{Statistical analysis}

The statistical analyses were carried out using the SAS-procedures (SAS Institute Inc. 1985). Litter size and interval between farrowing and grouping/weaning was analysed with the GLM procedure according to a model including the effects of housing system (2), farm within housing system (4 and 3) and agegroup ( 3 classes: 1 st parity, 2 nd-4th parity and $\geq 5$ th parity). The GLM procedure was also used to analyse differences in backfat thickness between housing systems. This model was the same as the one used to analyse litter size, but also included the interaction between housing systems and age group, and regressions within housing system on farrowing-togrouping interval, number of piglets at time of grouping, length of the lactation period and number of days between weaning and examination. In both models variation between herds within group was used as error term. A $\chi 2$-test was used to analyse differences between housing systems and between herds within housing system concerning all-or-none traits (mammary glands, legs and gait, external genital tract and skin). However, Fisher's exact test was used when expected frequencies were below 5 in more than $25 \%$ of the cells (Altman 1991). P-values, which denote the probability of having observed our data when the null hypothesis is true are given in the text. The following levels of significance were used: N.S. $=\mathrm{p}>0.05 ; *=\mathrm{p} \leq 0.05 ; * *$ $\mathrm{p}=\leq 0.01 ; * * *=\mathrm{p} \leq 0.001$.

\section{Results}

Average parity number was $3.7( \pm 2.1)$ in the G-farm group and $3.4( \pm 1.8)$ in the C-farm group. No significant differences in litter size or in intervals from farrowing to grouping or farrowing to weaning were found between the G- and C-farm groups (Table 1).

\section{Mammary glands}

As shown in Table 2, the frequency of sows with teat wounds was very high in both groups. However, wound frequency was lower 


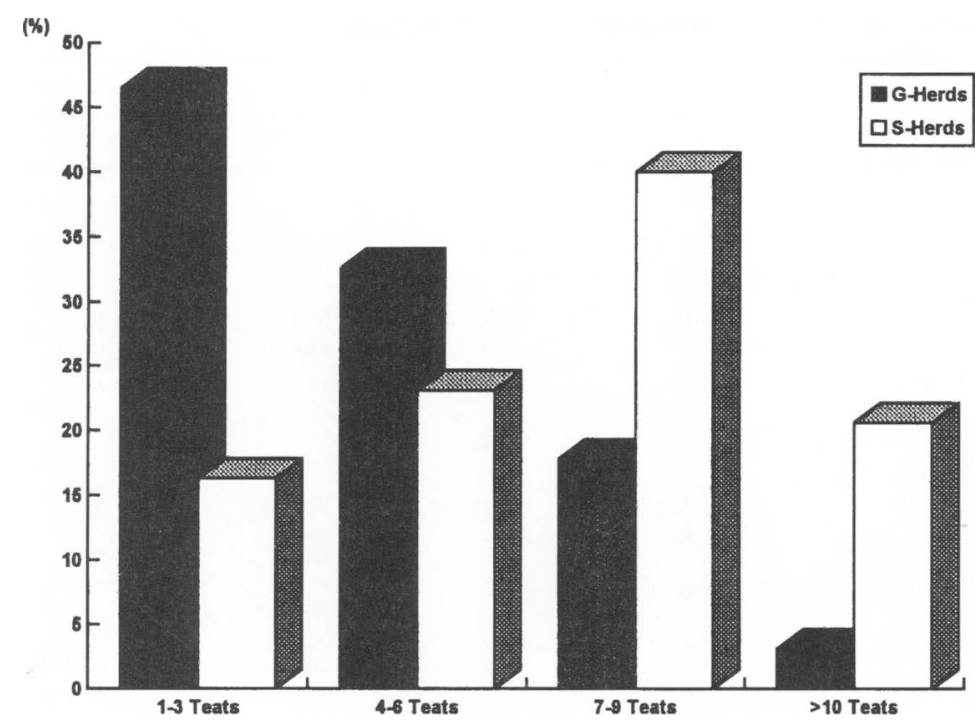

Figure 1. The number of teats affected in sows with teat wounds (\%).

in the G-farm group than in the C-farm group. A significant difference was also noted between G-farms, owing to the large variation among older sows ( $\geq 5$ th parity). Frequencies of teat wounds in primiparous sows were high and similar in the 2 groups, whereas multiparous sows in the G-farm group had a significantly lower frequency of wounds than multiparous sows in the C-farm group. Moreover, the average number of teats affected in sows with teat wounds was lower $(p<0.001)$ in the $\mathrm{G}$-farm group than in the C-farm group (Fig. 1). In most cases the wounds were located at the tip of the teat and occurred mainly as superficial epithelial injuries with only minor inflammation. Differences between the groups concerning udder skin wounds correspond well with the differences noted concerning teat wounds (Table 2). Preweaning atrophy of all mammary glands was noted in $6.6 \%$ of the sows in the G-farm group but not in any of the sows in the C-farm group (Table 2). Moreover, atrophied mammary glands were not found in any of the primiparous sows on the G-farms but were noted on $4.2 \%$ of the 2 nd- 4 th parity sows and in $12.1 \%$ of the older sows ( $\geq 5$ th parity). The differences between parity-number groups were significant $(\mathrm{p}<0.05)$.

The total frequency of sows with mastitis was the same in the 2 groups (Table 2), and in almost all sows no more than 3 glands were infected. Moreover, the frequency of chronic mastitis was equal in the 2 groups, whereas acute mastitis occurred more frequently in the $\mathrm{C}$-farm group than in the G-farm group (Table 2). However, high frequencies of acute mastitis were only found on 2 of the $\mathrm{C}$-farms $(12.8 \%)$, the frequency on the third C-farm $(2.7 \%)$ being about equal to that of the mean for the G-farms $(2.3 \%)$. A control program was established on the C-farms with high frequencies of acute mastitis, in connection with which sows with mastitis were either medically treated or culled after weaning. Acute mastitis did not occur in older sows $(\geq 5$ th par- 
Table 2. The percentage of sows with remarks on mammary glands.

\begin{tabular}{lcclcc}
\hline & G-farm group & C-farm group & \multicolumn{3}{c}{ Level of significance between } \\
\cline { 5 - 6 } & & & Groups & G-farms & C-farms \\
\hline No. of sows & 179 & 167 & & & \\
Teat wounds (total): & 72.3 & 97.0 & $* * *$ & $* *$ & N.S. \\
Within parity number: & 100 & 97.7 & N.S. & N.S. & N.S. \\
1. & 74.2 & 97.7 & $* * *$ & N.S. & N.S. \\
$2-4$ & 60.7 & 91.9 & $* * *$ & $* * *$ & N.S. \\
$\geq 5$ & 24.9 & 45.1 & $* * *$ & $* *$ & N.S. \\
Udder skin wounds (total): & & & & & \\
Within parity number: & 42.1 & 58.1 & N.S. & N.S. & N.S. \\
1. & 22.8 & 40.5 & $* * *$ & $* *$ & N.S. \\
$\geq 2$ & 6.6 & 0 & $* * *$ & N.S. & - \\
Mammary gland atrophy & 19.2 & 23.0 & N.S. & $*$ & N.S. \\
Mastitis (total): & 2.3 & 8.5 & $* *$ & N.S. & N.S. \\
Acute mastitis & 16.9 & 14.5 & N.S. & $*$ & N.S. \\
Chronic mastitis & & & & & \\
\hline
\end{tabular}

ity); moreover, $44.4 \%$ of the sows with acute mastitis were primiparous.

\section{Legs and gait}

There were no significant differences in locomotor disorders between the G-farm group and the C-farm group (Table 3). Furthermore, the total frequency of remarks on joints and hooves was the same in the 2 groups (Table 4), whereas the difference between herds was significant in both housing systems. Overgrown hooves were common, whereas other hoof injuries were rare in both groups. Moreover, locomotor disorders were significantly more frequent in sows with overgrown hooves than in sows that did not receive any remarks on joints and hooves, both in the G-farm group ( $\mathrm{p}=0.001)$ and in the $\mathrm{C}$-farm group $(p=0.001)$. Pooled data from all herds shows that locomotor disorders occurred in $38.8 \%$ of the sows with overgrown hooves but in only $10.1 \%$ of the sows without any joint abnormalities or hoof injuries.

\section{The external genital tract}

Only 2 sows in the G-farm group and 1 sow in the C-farm group showed discharge. Similarly, wounds in the vulva were rare and occurred with about the same frequency in the G-farm (4.0\%) and C-farm (3.6\%) groups. Moreover, there were no significant differences between herds within groups.

\section{Skin}

The total frequency of skin wounds - excluding wounds in mammary skin and the external genital tract - was similar in the 2 groups (Table 5). However, there were significant differences between farms in both housing systems: Among primiparous sows the frequency of skin wounds was higher in the G-farm group than in the C-farm-group, while there was no difference between farms within group concerning these sows. Injuries appeared mostly as superficial scratches with either a sparse transudation or bleeding or, if about to heal, covered with dry exudate. However, in the 
Table 3. The percentage of sows with locomotor disorders.

\begin{tabular}{lcclcc}
\hline & G-farm group & C-farm group & \multicolumn{3}{c}{ Level of significance between } \\
\cline { 5 - 6 } & & & Groups & G-farms & C-farms \\
\hline No. of sows & 179 & 164 & & & \\
Lameness: & & & & & \\
- Front leg & 3.9 & 1.8 & & & \\
- Hind leg & 5.6 & 3.1 & & N.S. & N.S. \\
- Total & 9.5 & 4.9 & N.S. & N.S. & $*$ \\
Abnormal walk & 10.0 & 6.8 & N.S. & N.S. & $*$ \\
Total & 19.5 & 11.7 & N.S. & & \\
\hline
\end{tabular}

Table 4. The percentage of sows with remarks on joint and hooves.

\begin{tabular}{lcclcc}
\hline & G-farm group & C-farm group & \multicolumn{3}{c}{ Level of significance between } \\
\cline { 5 - 6 } & & & Groups & G-farms & C-farms \\
\hline No. of sows & 175 & 164 & & & \\
Overgrown hooves & 18.3 & 12.8 & N.S. & $* * *$ & $*$ \\
Hoof injury & 2.3 & 1.3 & N.S. & N.S. & N.S. \\
Joint remarks & 4.6 & 9.1 & $*$ & N.S. & $* *$ \\
Total & 24.0 & 23.2 & N.S. & $* *$ & $*$ \\
\hline
\end{tabular}

$\mathrm{a}=$ Deformities, swellings, exostosis or bursitis.

scapular region injuries were deeper, and abscesses often occurred over the skeletal protrusions. Wounds in the scapular region occurred more frequently in the $\mathrm{C}$-farm group than in the G-farm group (Table 5).

\section{Backfat thickness}

At time of weaning, average backfat thickness was higher $(\mathrm{p}=0.01)$ in the G-farm group $(14.0 \mathrm{~mm})$ than in the C-farm group (11.6 $\mathrm{mm})$. However, this difference only concerned multiparous sows; in primiparous sows backfat thickness was about the same in the 2 groups (Table 6). In the G-farm group, backfat thickness was lower in primiparous sows than in multiparous ones, whereas in the C-farm group backfat thickness was similar in the 3 age-groups.

\section{Discussion}

The frequency of sows with wounds on teats and udder-skin at the time of weaning was lower in the G-farms than in the C-farms. Furthermore, group-housed sows with teat wounds had fewer teats affected compared with conventionally-housed sows. This indicates that sow-piglet interactions decrease when sows are grouped during lactation. The piglets become more active in exploring the environment in group-housing systems, and thus interact less frequently with the sow (Stolba et al. 1990). Moreover, when in the process of establishing and maintaining a dominance order, the sow's attention is focused on other sows (Jensen \& Wood-Gush 1984, Stolba \& Wood-Gush 1989). The decrease in sow-piglet interactions in group- 
Table 5. The percentage of sows with skin wounds.

\begin{tabular}{|c|c|c|c|c|c|}
\hline & \multirow{2}{*}{ G-farm group } & \multirow{2}{*}{ C-farm group } & \multicolumn{3}{|c|}{ Level of significance between } \\
\hline & & & Groups & G-farms & C-farms \\
\hline No. of sows & 170 & 166 & & & \\
\hline Total & 52.9 & 47.0 & N.S. & $* *$ & $* * *$ \\
\hline \multicolumn{6}{|l|}{ In parity number: } \\
\hline 1. & 82.3 & 30.9 & $* * *$ & N.S. & N.S. \\
\hline $2-4$ & 52.8 & 55.4 & N.S. & N.S. & $* * *$ \\
\hline$\geq 5$ & 44.1 & 50.0 & N.S. & N.S. & $* *$ \\
\hline Scapular abscesses & 3.0 & 13.4 & $* * *$ & N.S. & $*$ \\
\hline
\end{tabular}

Table 6. Backfat thickness (mm) at weanıng in parity number groups (least square means).

\begin{tabular}{lccc}
\hline & G-farm group & C-farm group & Level of significance \\
\hline No. of sows & 178 & 167 & \\
Parity number & & & $10.7^{\mathrm{a}}$ \\
1 & $11.4^{\mathrm{a}}$ & $11.9^{\mathrm{a}}$ & N.S. \\
$2-4$ & $14.7^{\mathrm{b}}$ & $12.3^{\mathrm{a}}$ & $* *$ \\
$\geq 5$ & $15.8^{\mathrm{b}}$ & $* *$ & \\
\hline
\end{tabular}

a, b. Values with different superscripts, withın row, differ significantly $(\mathrm{p}<0.05)$.

housing systems is reflected in a decrease in suckling frequency (Newberry \& Wood-Gush 1985, Stolba et al. 1990). Preweaning atrophy of mammary glands was evident in some of the group-housed sows in the present study, indicating that some sows wean their litters during the lactation period. This can be taken as further evidence that contact between the sow and her piglets decreases when sows are kept in groups. However, mammary gland atrophy did not occur in primiparous, grouphoused sows, and the frequency of teat- and mammary skin wounds was high and similar in group-housed and conventionally housed, primiparous sows. This suggests that primiparous sows, in contrast to multiparous ones, maintain a close relation to their offspring after grouping. The frequency of teat- and mammary skin wounds varied considerably between the G-farms, owing to large variation among multiparous sows. In contrast, there was no such variation between the $\mathrm{C}$-farms. This indicates that multiparous sows show large differences in concern of their offspring, but that these differences only become manifested if the sows are group housed.

Mastitis has previously been found in 18.8 to $23 \%$ of mainly dry or recently weaned sows from commercial abattoirs (Delgado \& Jones 1981, Bollwahn \& Meermeier 1989), which corresponds well with the total proportion of sows with mastitis recorded in the present study.

The total frequency of sows with mastitis did not differ between housing systems, whereas acute mastitis was more common in the C-farm group. However, this difference was due to high frequencies of acute mastitis in 2 
of the $\mathrm{C}$-farms, the 3rd $\mathrm{C}$-farm having an acute mastitis frequency similar to that of the $\mathrm{G}$-farms. These findings suggest that the housing system was not a major factor determining the occurrence of mastitis. By contrast, the introduction and proliferation of infectious agents in the population are probably of great importance. A diverse flora $(\alpha-, \beta$ - or non-haemolytic streptococci, $P$. multocida, $A$. pyogenes and $S$. aureus) was found in a small number of milk samples collected from sows with mastitis (Hultén unpublished), which agrees with previous reports on mastitis in sows (Ringarp 1960, Delgado \& Jones 1981, Ross et al. 1981, Bollwahn \& Meermeier 1989). To explain the high frequency of acute mastitis on 2 of the conventional farms in the present study a combination of infectious agents, management and environmental factors has probably to be considered.

The frequency of locomotor disorders was the same in the 2 housing systems. It has previously been reported that exercise improves locomotor ability (Grøndalen 1974, Perrin \& Bowland 1977) and that the frequency of leg weakness is higher in individually confined sows than in group-housed ones (Elliot \& Doige 1973, Sather \& Fredeen 1982). However, other reports question the beneficial effect of increased space on locomotor ability (Nakano et al. 1981, Sather 1987). In the present study all sows were able to move freely during the gestation period, and the farrowing pens in the conventional system were large enough to allow the sows to walk around, which could explain why the frequency of locomotor disorders did not differ between housing systems.

Osteochondrosis has been suggested to be the most common cause of lameness since it affects a high proportion of the swine population (Grøndalen 1974, Reiland 1975, Lundeheim 1987) and causes clinical symptoms when severe defects occur (Nakano et al. 1981, Lundeheim 1987). However, the condition of the feet also strongly influences locomotor ability, and foot injuries can be a major cause of lameness (Penny et al. 1963, 1965). In the present study overgrown hooves were common in both groups, whereas other hoof injuries were rare. This was probably due to the fact that deep litter was used as bedding in the dry sow section in both housing systems. Straw is known to have beneficial effects on hoof health (Penny et al. 1965); in contrast, rough concrete floor can lead to a high frequency of hoof injuries (Penny et al. 1963, 1965, Smith \& Robertson 1971). Previous studies have mainly emphasised the relationship between locomotor disorders and cracks or infections in the hoof (Penny et al. 1963, 1965, Smith \& Robertson 1971). However, the present study shows that there is also a strong relationship between locomotor disorders and overgrown hooves. The body weight is shifted to the heal when the hoof is overgrown which might cause overstraining of parts of the locomotor apparatus. However, variation between farms was considerable in many of the locomotor parameters assessed, indicating that leg soundness is strongly influenced by specific conditions on the farm.

The frequency of injuries in the external genital tract was low, in accordance with previous studies of sows group housed during gestation (Svendsen et al. 1990).

The frequency of skin wounds was equal in the 2 groups, which was probably due to the fact that the sows were grouped in the breeding and in the dry sows section in both housing systems. Nevertheless, primiparous sows had a higher frequency of wounds in the G-farm group than in the C-farm group, probably owing to fights occurring in connection with the establishment of dominance hierar- 
chies at time of grouping during lactation. The social rank attained shortly after grouping is influenced by body size and weight (Beilharz \& Cox 1967, Mauget 1981), which makes it likely that primiparous sows obtain a low rank. Scapular abscesses seemed to occur more frequently on the C-farm, probably because this group had less bedding and a lower backfat thickness.

In the C-farm group backfat thickness was about equal to that reported from previous studies on conventionally housed, multiparous sows fed according to scale (Whittemore et al. 1980). On the other hand, sows in the G-farm group had a higher backfat thickness. The main reason for this is probably the higher food allowance during the group-housing period. However, a decrease in suckling frequency among multiparous sows in the group-housing system, as indicated by the occurrence of mammary gland atrophy and the lower frequency of teat wounds, probably reduced the demand for metabolites for milk production, and thereby promoted maternal storage of ingested nutrients. Primiparous sows had a lower backfat thickness than multiparous sows in the G-farm group, suggesting that the primiparous sows obtained less food in the group-housing system. In addition, the high suckling intensity in first-parity sows, as indicated by the high frequency of teat- and udder skin wounds, could also have contributed to the difference. The primiparous sows probably possess a low rank which causes less access to food (Beilharz \& Cox 1967, Mauget 1981, Csermely \& Wood-Gush 1990).

\section{Conclusion}

The present study shows that wounds on teats and mammary skin at the time of weaning are less common among group-housed sows than among conventionally-housed sows. Further- more, mammary gland atrophy occur in group-housed sows but not in conventionallyhoused ones. This indicates that the interaction between the sow and her litter decreases when the sows are grouped during lactation. By contrast, these differences do not occur in primiparous sows, suggesting that they maintain close contact with their offspring after grouping. The frequency of locomotor disorders does not differ between systems, but overgrown hooves are common when sows are kept on deep litter. At the time of weaning in the group-housing system, backfat thickness is lower in primiparous sows than in multiparous sows, and primiparous, grouphoused sows has a higher frequency of skin wounds than conventionally housed, firstparity sows. These findings indicate that primiparous sows, due to low rank, have less access to food during the group housing period.

\section{Acknowledgements}

This work was supported by grants from the Farmer's Research Council for Information and development, the Swedish Board of Agriculture and the Swedish University of Agricultural Sciences. The authors wish to thank Dr. Jan Håkansson for fruitful discussions and valuable advise.

\section{References}

Altman DG: Practical statistics for medical research. (1st ed.). Chapman and Hall, London, 1991.

Andreasson E, Andersson C: Digivande suggor i små grupper. Dygnsrytm, sociala interaktioner och digivningsbeteende. (Group-housed lactating sows in small groups: diurnal rhythm, social interactions and suckling and nursing behaviour). Swedish University of Agricultural Sciences, Uppsala, Sweden. 1992, 1-56.

Beulharz RG, Cox DF: Social dominance in swine. Anim. Behav. 1967, 15, 117-122.

Bollwahn W, Meermeler D: Haufigkeit und Diagnostik chronischer Gesaugeverändrungen beı Zuchtsauen (Schlachtbefunde). (Frequency and diagnosis of chronic alterations in mammary glands of sows (abattoir survey)). Berl. Múnch. 
Tierarztl. Wschr. 1989, 102, 223-227.

Bryant MJ, Rowlinson P: Nursing and suckling behaviour of sows and their litters before and after grouping in multi-accomodation pens. Anim. Prod. 1984, 38, 277-282.

Bryant MJ, Rowlinson P, Van Der Steen HAM: A comparison of the nursing and suckling behaviour of group- and individually-housed sows and their litters. Anim. Prod. 1983, 36, 445-451.

Backstrom L: Environment and animal health in piglet production. Acta vet. scand. 1973, Suppl 41, 1-240.

Csermely D, Wood-Gush DGM: Agonistic behaviour in grouped sows. II. How social rank affects feeding and drinking behaviour. Boll. Zool. 1990. 57, 55-58.

Delgado JA, Jones JET: An abattoir survey of mammary gland lesions in sows with special reference to bacterial flora of mammary abscesses. Br. vet. J. 1981, 137, 639-643.

Dewey CE, Wllson MR, Friendship RM, Palmer NC: An observational study of lameness in breedingstock swine in Ontario. Proc. Int. Pig Vet. Soc. Rio de Janeiro 1988, 238.

Ellot JI, Doige CE: Effects of type of confinement on performance and on the occurrence of locomotory disturbances in market pigs. Can. J. Anim. Sci. 1973, 53, 211-217.

Grøndalen T. Osteochondrosis and Arthrosis in pigs; II. Incidence in breeding animals. Acta vet. scand. 1974, 15, 26-42.

Jensen P: Observations on the maternal behaviour of free-ranging domestic pigs. Appl. Anim. behav. Sci. 1986, 16, 131-142.

Jensen P, Florén K, Hobroh B: Peri-parturient changes in behaviour in free-ranging domestic pigs. Appl. Anim. behav. Sci. 1987, 17, 69-76.

Jensen P, Redbo I: Behaviour during nest leaving in free-ranging domestic pigs. Appl. Anim. behav. Sc1. 1987, 18, 355-362.

Jensen P, Wood-Gush DGM: Social interactions in a group of free-ranging sows. Appl Anım. behav. Sci. 1984, 12, 327-337.

Lambert RJ, Ellis M, Rowlinson P, Saville CA: Influence of housing/feeding system on sow behaviour. Anim. Prod. 1983, 36, 532.

Lent PC: Mother-infant relationships in ungulates. In: Geist U, Walther F (eds.): The behaviour of ungulates and its relationship to management. 1974, IUCN, Morger, Switzerland, 14-55.

Lundeheim N: Genetic analysis of osteochondrosis and leg weakness in the swedish pig progeny test- ing scheme. Acta agric. scand. 1987, 37, 159-173.

Mauget $R$ : Behavioural and reproductive strategies in wild forms of sus scrofa (European wild boar and feral pigs). Curr. Top. Vet. Med. Anim. Sc1. 1981, Vol. II, 3-13.

Meese $G B$, Ewbank R: The establishment and nature of the dominance hierarchy in the domesticated pig. Anim. Behav. 1973, 21, 326-334.

Nakano T, Aherne FX, Thompson JR: Effect of housing system on the recovery of boars from leg weakness. Can. J. Anim. Sci. 1981, 61, 335-342.

Newberry RC, Wood-Gush DGM: The suckling behaviour of domestic pigs in a semi-natural environment. Behaviour. 1985, 95, 11-25.

Penny RHC, Osborne AD, Wright AI. The causes and incidence of lameness in store and adult pigs. Vet. Rec. 1963, 75, 1225-1235.

Penny RHC, Osborne AD, Wright AI: Foot-rot in pigs: Observations on the clinical disease. Vet. Rec. 1965, 77, 1101-1108.

Perrin WR, Bowland JP: Effects of enforced exercise on the incidence of leg weakness in growing boars. Can. J. Anim. Sci. 1977, 57, 245-253.

Reiland S: Osteochondrosis in the pig. A morphologic and experimental investigation with special reference to the leg weakness syndrome. Thesis. The Royal Veterinary College, Stockholm, Sweden. Acta Rad. 1975, Suppl. 1-118.

Ringarp N: Clinical and experimental investigations into a postparturient syndrome with agalactia in sows. Acta agric. scand. 1960, Suppl 7, 1-166.

Ross RF, Orning AP, Woods RD, Zımmermann BJ, Cox DF, Harris $D L$ : Bacteriologic study of sow agalactia. Amer. J. vet. Res. 1981, 42, 949-955.

SAS Instttute Inc: SAS user's guide. Statistics Version 5. Cary, N. C. 1985.

Sather AP: A note on the changes in leg weakness in pigs after being transferred from confinement housing to pasture lots. Anim. Prod. 1987, 44, 450-453.

Sather AP, Fredeen HT: The effect of confinement housing upon the incidence of leg weakness in swine. Can. J. Anim. Sci. 1982, 62, 119-1128.

Signoret JP, Baldwin D, Fraser D, Hafez ESE: The behaviour of swine. In: The behaviour of domestic animals. 1975, Balliere Tindal, London, 295329.

Smith WJ, Robertson AM: Observations on injuries to sows confined in part slatted stalls. Vet. Rec. 1971, 89, 531-533.

Stangel $G$, Jensen P: Behaviour of semi-naturally kept sows and piglets (except suckling) during 10 
days post partum. Appl Anim. Behav. Sci. 1991, 31, 211-227.

Stolba A, Henderson R, Wechsler B: The influence of different social and physical environments on the incidence of lactational oestrus in sows. Appl. Anim. Behav. Sci. 1990, 27, 269-276.

Stolba A, Wood-Gush DGM: The behaviour of pigs in semi-natural environment. Anim. Prod. 1989, 48, 419-425.

Svendsen J, Andersson M, Olsson A-C, Rantzer D, Lundqvist $P$ : Group housing of sows in gestation in insulated and unınsulated buildıngs. Swedish University of Agricultural Sciences, 1990, 1-197.

Whittemore CT, Franklin MF, Pearce BS: Fat changes in breeding sows. Anim. Prod. 1980, 31, 183-190.

\section{Sammanfattning}

En studie av suggornas halsa $\iota$ ett grupphållningssystem for digivande suggor.

Suggornas hảsotıllstånd vid avvanjningen registrerades $i$ fyra besättnıngar som grupperade suggorna från två veckor efter grisningen till avvanjnıngen (G-gruppen), samt 1 tre besáttningar (kontroller) som inhyste suggorna enskilt under hela diperıoden (K-gruppen). Samtliga suggor var svensk yorkshire $\times$ svensk lantras. Den dagliga fodergivan var lika i båda grupperna, forutom under grupphållningsperioden då suggorna i G-gruppen utfodrades ad lıbl- tum. Diperioden var fem-sex veckor lång. Samtliga suggor grupperades 1 betackningsavdelningen och inhystes gruppvis på djupstrobadd under draktıghetsperioden. I denna studie halsoundersoktes 179 suggor från G-gruppen och 167 suggor från K-gruppen vid avvanjningen ( \pm 4 dagar).

Andelen suggor med sårskador på spenar och juverhud var lagre $(\mathrm{p}<0.001)$ bland de aldre suggorna i G-gruppen an $1 \mathrm{~K}$-gruppen, medan det ej forelåg någon skillnad mellan grupperna avseende forstagrisarna. Tillbakabildat juver påvisades bland de aldre suggorna 1 G-gruppen, medan juveratrofi ej forekom bland forstagrisarna 1 G-gruppen eller bland suggorna $1 \mathrm{~K}$-gruppen. Dessa fynd indikerar att kontakten mellan suggan och smågrisarna minskar vid grupphållning vad avser de aldre suggorna, medan forstagrisarnas kontakt med avkomman ej forandras. Frekvensen juverinflammation var lika i båda grupperna. Andelen suggor med rorelsestorningar var också lıka 1 båda grupperna. Forvuxna klovar sågs relatıvt ofta $i$ båda systemen, vilket kan forklaras av att samtliga suggor inhystes gruppvis på djupstrobadd under draktighetsperioden. Ett starkt samband $(p=0.001)$ mellan forvuxna klovar och rorelsestorningar påvisades. Spaicktjockleken var lagre hos forstagrisarna an hos de aldre suggorna 1 G-gruppen medan andelen forstagrisare med hudskador var hogre i G-gruppen an 1 C-gruppen, vilket talar for att forstagrisarna hade samre t1llgång till foder under grupphållningsperioden till foljd av låg rangstallning.

(Recelved Aprll 21, 1994; accepted January 10, 1995).

Reprints may be requested from: F. Hultén, Department of Obstetrıcs and Gynaecology, P.O. Box 7039, Faculty of Veterinary Medicine, Swedish University of Agricultural Sciences, S-750 07 Uppsala, Sweden. 